\title{
Government Size and Quality of Governance: Does State Size Matter?
}

Primož Pevcin †

University of Ljubljana, Faculty of Public Administration, Gosarjeva Ulica 5, Ljubljana/Slovenia

\begin{tabular}{l}
\hline ARTICLE INFO \\
\hline Article History \\
Received 1 August 2020; \\
Accepted 11 January 2021 \\
\hline JEL Classifications \\
H11, H50, H83
\end{tabular}
\begin{abstract}
Purpose:

Small state studies has emerged as a discipline, and this discipline has been initially dominated mainly by the issues of vulnerability and a lack of capacities of small states, although these issues have been gradually replaced by the discussions on the potential opportunities of small states, not just their challenges. Within this framework, the consideration needs to be done also on the effect of the state size on the economics, governance and public management, among others.
\end{abstract}

Design/methodology/approach:

The current theorizing in small state studies focuses on the specifics of the small economy modelling and governance. The existing economic literature has occasionally stressed the relations between the size of the state and size of government, but with rather mixed empirical results. Moreover, relations between state size and quality of governance has also been emerging issue. This study would like to integrate both approaches. The empirical research utilizes cross-national comparative investigation based on the data for 44 European states; and we specifically assess, in addition to the existing approaches, how budgetary and non-budgetary scope of government differentiates among smaller and larger states.

Findings:

The results of the study suggest that the effect of the size of the state does not necessary favour larger states in respect to the smaller size of government and quality of governance. Thus, although potential scale economies matter regarding the public services' provision, the structure of spending, institutional context, and innovations in public service delivery modes also have the role in shaping scope and functions of the government, whereas quality of governance seems to be independent regarding the state size, at least in the European

Keywords:

Small states; Governance; Governmental interventionism; Public goods and services; Innovations; Great Lockdown context.

Research limitations/implications:

Analysis is limited to the cluster of European states, and the results should be interpreted within this context.

Originality/value:

After the World War II the number of states has increased substantially, in fact, it has tripled. We are currently living in the era of small states, as more than one third of the existing two hundred and more states around the globe are actually small, if we assess the multiple criteria combination. In this context, this paper would like to add to the development of the field of small state studies.

\section{Introduction \\ $\dagger$ Corresponding author: Primož Pevcin \\ e-mail: primoz.pevcin@fu.uni-lj.si}

Numerous categorizations or classifications of states (i.e., "independent" countries, as labels can simply be utilized interchangeably) exist in the literature; i.e., strong versus weak states, high-income versus low-income states, sustainable versus fragile states, developed versus developing states, small versus large states, etc. These classifications depend on the criteria being used for categorization, and often ranks in between exists between the extremes. Small versus large states classification uses the size of the country as the main criterion, although this criterion can have several inputs, e.g. number of population, surface, GDP etc., which can be applied also simultaneously. In practice, the number of population usually serves as the main input for classification of states into various size-based categories: micro, small, medium-sized, and large states. Specifically, if the number of population is taken as the main criterion for categorizing states according to the size, the World Bank stipulates that 1.5 million 
residents is officially threshold for small states, but this threshold is heavily challenged by some due to the population and globalization shifts, where 10 million threshold is taken as more appropriate (see, e.g., Maass, 2009).

When addressing the topics related to small state studies, we should bear in mind that state size, which is being micro, small, medium or large state, is actually and endogenous variable as states are formed and are able to survive given the appropriate economic, political and social conditions. The elaboration on the state size as the endogenous variable has been promoted by Alesina (2003), since the evidence indicates that the size of the countries is very diverse, that their numbers variated very much throughout the history and also the meaning, functioning and role of the state varies. In this context, what we can observe that after the World War II, in particular, the number of states has increased substantially. In fact, this number has tripled. It can be argued that we are currently living in the era of small states, as more than one third of the existing 215 states around the globe are actually small (see, e.g., Brito, 2015), if we assess the multiple criteria combination. It might be argued, that we are experiencing the area of small states.

Consequently, small state studies has emerged as a discipline, and this discipline has been initially dominated mainly by the issues of vulnerability and a lack of capacities of small states, although these issues have been gradually replaced by the discussions on the potential opportunities of small states, not just their challenges (see, e.g., Thorhallson, 2019). The current theorizing thus focuses also on the specifics of the small economy modelling that has been viable due to the globalization trends (see, e.g., Skilling, 2018; Farrell, 2020), as globalization processes increase transmission of economic disturbances and pose further exposure of states with larger share of fixed budgetary expenditures (Bukowski and Bukowska, 2017). In this context, these trends have been further reinforced with the onset of the COVID-19 induced pandemic, which is alternatively labelled the Great Lockdown crisis.

Within this framework, the consideration needs to be done also on the effect of the state size on the economics, governance and public management, among others. The current theorizing in small state studies focuses on the specifics of the small economy modelling and governance, whereas the existing economic literature has occasionally stressed the relations among the size of the state and size of government, and relations among size of the state and quality of governance. This study would like to integrate both approaches, and put additional evidence to assess the issue of specifics both in the form of governmental interventionism as well as in the dimensions of governance, when we observe states with different size. This paper proposal intends to address the question if there is any difference regarding the size and scope of government between smaller and larger states, and if this difference can be observed potentially in the quality of governance.

\section{Theoretical Framework}

The economics of the state size thus treats it basically as the trade-off between the benefits of the size versus the costs of heterogeneity of population preferences (Alesina et al., 2005). Namely, the clear benefits of the larger state size are related to larger available domestic market size and thus implicitly less reliance on foreign trade, more diverse industry structure, larger availability of human potential, both in numbers as well as in their diverse capabilities. Moreover, per capita costs of several public goods and services are lower, either because more taxpayers can pay for them, or they have important scale economies or simply because the indivisibility is not implicitly increasing them. Notwithstanding, the aforementioned benefits are mostly economic in their nature, but there are also political and social benefits to the size, like increased military security, larger bargaining power in comparison to other states, larger international role of the state, larger possibility for internal redistribution etc. Since the focus of the paper stands on economic issues, only those are addressed. In contrast, larger states might experience also some costs that come from the heterogeneity of population, which means that different preferences should be followed, which increases the costs, like distributional ones, and also the ties that are connecting the people might be looser, which generates difficulties in creating uniform and sustainable policies. Consequently, there is a trade off, and like in any organization, you might have also in the context of the state size the diseconomies of scale, arising mostly through administrative and congestion costs. We might argue that there is some ground also for the theory on the optimal size of state. Nonetheless, we will focus only on the economics of small states.

Economic literature has stressed the relations among the size of the country and governmental interventionism. For example, Alesina and Warcziarg (1998) argue that the size of government correlates negatively with country size and positively with trade openness. They have shown that smaller states have a larger share of government consumption in GDP, and are also more open to trade. Moreover, they argue that these empirical observations are consistent with recent theoretical models explaining country formation and break up. Namely, larger states can afford to be closed, while small states face stronger incentives to remain open; conversely, as trade liberalizes, regional and cultural minorities can afford to split because political borders do not identify the size of market. Similarly, Rodrik (1998) has found a strong positive association between openness and government size. He explains this paradox by arguing that government expenditures are used to provide social insurance against the risk of terms of trade shocks that open economies face. This indicates that government consumption and expenditures play a risk-reducing role in economies exposed to a significant amount of external risk. Goldsmith (1999) has justified the observation on the activist government in small states as being a buffer to vulnerability. Following, this should effect the optimal size of welfare state, which is bound to be larger the higher are the risks that it cannot insure, which are referenced as the socalled background risks (Eichner and Wagener, 2002). Some recent studies have tried to put additional evidence on the relations among state size and government size. For instance, Jetter and Parmeter (2015) have pointed out that economies that are more open not necessarily have bigger governments, but country size may be related to 
government size, as smaller states should have bigger government, although they admit that using different datasets, timeframes, and sample countries changes conclusions.

In addition, the existing literature has also investigated the relationships between state size and the quality of governance (i.e., the rule of law, regulatory involvement of government in economy and society, investor friendliness, etc.). These are indicators that point to the other part of governmental interventionism, which is not observed in governmental finances, but it is also very important. Since it is often hidden, i.e. not directly and explicitly observed, we can label this as the non-budgetary government, although this can be of particular relevance for the regulation. The other indicators tend to correspond more suitably to the quality of governance, although the distinction is not straightforward as regulation might also be part of quality of governance and not measure of government size per se (Kaufmann et al., 2007), or they might be also measures of governmental effectiveness (TheGlobalEconomy, 2020).

For instance, Streeten (1993) has stated that collective action problems can be solved more easily in smaller states, and supervision is much easier to be performed. Rodrik (2000) has stressed that quality of institutions is much more important in smaller states, as they function as the tool for conflict management, and this is more important for smaller states to balance the impacts of shocks. Pryor (2001) has hypothesized that state size and laissez-faire are negatively correlated, in some way reflecting a desire by the citizenry in larger states for greater protection against possible excesses of larger (and more influential) enterprises; thus smaller states should be less regulated. Moreover, Olsson and Hansson (2011) have pointed out the negative relationship between the size of the country and the rule of law, as the institutional quality has a character of local public good.

This theoretical insight suggest that relationship between state size and size of government is a rather complex issue, and empirical investigations are warranted. If we would follow assumptions stated above, smaller states should have larger budgetary government and smaller non-budgetary government, on average at least, in comparison to larger states. Given the context, this study would like add to the existing research by providing some additional databased evidence on the relations among state size, government size and quality of governance. Specifically, the paper follows the logic of observational study, as we do not either make involvements into observed units nor do we control for the effects of secondary variables (National Research Council, 2012).

\section{Methodology and Data}

The cross-national comparative investigation based on the data for 44 European countries is utilized to assess the relationships among state size and government size. Specifically, we introduce the notion of budgetary and nonbudgetary scope of government, and how these two clusters differentiate among smaller and larger states. Under budgetary government, we assume and assess the various types of governmental spending categories (consumption spending, transfer spending, total spending) and tax burden, all these measured in relative terms as a share of gross domestic product (GDP). These spending categories are perceived as standard measures of direct governmental interventionism. Under non-budgetary government, we assume and assess the so-called not directly observable and foremost not directly measurable governmental activities, which come into the forms of regulation, investment freedom, judicial effectiveness, legal system and property rights, and government integrity. Although there is a tendency to describe this part of not directly measurable governmental interventionism only as regulation, as pointed in the previous chapter, we decided to investigate also additional indicators that are associated, according to the World Bank, with the dimensions and quality of governance, as we assume there might be some relations also among those indicators and state size.

This study is based on the exploratory research, i.e. we are investigating the issue that is not clearly defined and we thus want to give a better understanding of this issue and potential directions for additional future research endeavours (Babbie, 2007). Our sample of 44 European countries is split into several clusters, the first cluster containing countries, which have less than 1.5 million residents, which is corresponds to the strictest, World Bank induced, definition of small state. This cluster includes states like Iceland, Malta, Luxembourg, Montenegro, Cyprus, and Estonia. The second cluster contains countries with the population between 1.5 and 4 million residents, and this includes states like Slovenia, North Macedonia, Latvia, Armenia, Albania, and Lithuania. The third cluster includes countries that have less than 7.5 million residents. This cluster includes Ireland, Moldova, Croatia, Bosnia and Herzegovina, Norway, Georgia, Finland, Slovakia, Denmark, and Israel. The fourth cluster includes states that have population in the range 7.5 to 10 million residents, which corresponds to one of the most recent demarcations on the threshold for small state definition Bulgaria, Switzerland, Austria, Sweden, Serbia, and Hungary. The fifth cluster of states includes the medium-sized one with the population between 10 and 25 million, which contains states like Czechia, Belarus, Belgium, Portugal, Greece, Netherlands, and Romania. The last, sixth, cluster includes both medium-sized and large European states that have population larger than 25 million. This cluster includes states like Poland, Spain, Ukraine, Italy, United Kingdom, France, Turkey, Germany, and Russia. It needs to be acknowledged that the states are clustered only according to the criteria of state size, and clusters are not symmetrical, since within the Europe mainly small states prevail, and this needs to be taken into account when doing clustering. More specifically, for the purpose of empirical analysis we consider states belonging to cluster 1-4 as smaller states, and states belonging to clusters 5 and 6 as larger states. Thus, the empirical part follows the binary logic that prevails in the literature, but for the descriptive part, also the clusters' averages are added, in order to get an additional insight into the issue. Namely, we follow the logic of exploratory interpretative research, thus taking this analysis as a medium to get potential additional insight into the researched topic. 


\section{Results and Discussion}

Table 1 presents the outputs on the groupings of states into size clusters as described in the methodology part. Although the states analysed are all very diverse, it is evident that the size variable obviously does not play a role in influencing the size of the so-called "budgetary" government, which is not in line with theoretical predictions, in particular for the governmental consumption spending. Namely, the evidence portrayed in the table indicates that there are no major variations regarding the relative amount of governmental spending between different clusters of states, if we categorize them according to their size.

Table 1: Evidence on the extent of budgetary part of government for selected European states

\begin{tabular}{|c|c|c|c|c|c|c|c|c|c|}
\hline $\begin{array}{l}\text { State/ } \\
\text { Indicator }\end{array}$ & \begin{tabular}{|} 
Gov't con- \\
sumption \\
expen- \\
diture \% of \\
GDP
\end{tabular} & $\begin{array}{c}\text { Gov't } \\
\text { transfer } \\
\text { expen- } \\
\text { diture \% } \\
\text { of GDP }\end{array}$ & $\begin{array}{c}\text { Gov't } \\
\text { Expen- } \\
\text { diture \% } \\
\text { of GDP }\end{array}$ & $\begin{array}{c}\text { Tax } \\
\text { Burden } \% \\
\text { of GDP }\end{array} \mid$ & $\begin{array}{l}\text { State/ } \\
\text { Indicator }\end{array}$ & $\begin{array}{c}\text { Gov't con- } \\
\text { sumption } \\
\text { expenditure } \\
\% \text { of GDP }\end{array}$ & $\begin{array}{l}\text { Gov't } \\
\text { transfer } \\
\text { expen- } \\
\text { diture \% } \\
\text { of GDP }\end{array}$ & $\begin{array}{l}\text { Gov't } \\
\text { expen- } \\
\text { diture \% } \\
\text { of GDP }\end{array}$ & $\begin{array}{c}\text { Tax } \\
\text { Burden } \% \\
\text { of GDP }\end{array}$ \\
\hline Iceland & 32.02 & 7.99 & 43.2 & 36.4 & Bulgaria & 20.46 & 15.74 & 34.7 & 28.0 \\
\hline Malta & 25.97 & 13.19 & 38.3 & 33.6 & Switzerland & 18.24 & 14.07 & 34.3 & 27.8 \\
\hline Luxembourg & 35.56 & 22.99 & 42.2 & 37.1 & Austria & 27.27 & 25.82 & 50.2 & 42.7 \\
\hline Montenegro & 20.35 & 18.70 & 47.4 & 36.1 & Sweden & 37.14 & 20.17 & 49.4 & 44.1 \\
\hline Cyprus & 17.83 & 14.32 & 38.7 & 33.6 & Serbia & 18.09 & 23.66 & 42.8 & 38.4 \\
\hline Estonia & 28.19 & 14.95 & 40.4 & 34.7 & Hungary & 28.88 & 17.78 & 47.7 & 39.4 \\
\hline Average - c1 & 26.65 & 15.36 & 41.70 & 35.25 & Average - c4 & 25.01 & 19.54 & 43.18 & 36.73 \\
\hline Slovenia & 25.99 & 18.90 & 45.4 & 37.0 & Czechia & 29.03 & 24.89 & 40.0 & 34.0 \\
\hline N. Macedonia & 19.40 & 20.49 & 31.6 & 24.8 & Belarus & 22.71 & 20.83 & 44.2 & 23.8 \\
\hline Latvia & 22.68 & 11.44 & 37.8 & 30.2 & Belgium & 31.53 & 29.82 & 53.2 & 44.2 \\
\hline Armenia & 15.30 & 8.76 & 26.4 & 21.3 & Portugal & 21.57 & 19.88 & 46.3 & 34.4 \\
\hline Albania & 12.01 & 9.64 & 29.5 & 24.9 & Greece & 22.45 & 23.05 & 50.6 & 38.6 \\
\hline Lithuania & 21.07 & 13.84 & 34.1 & 30.2 & Netherlands & 35.86 & 24.30 & 43.6 & 38.8 \\
\hline Average - c2 & 19.41 & 13.84 & 34.13 & 28.07 & Romania & 18.55 & 11.42 & 32.1 & 26.0 \\
\hline Ireland & 27.30 & 11.46 & 27.4 & 23.0 & Average - c5 & 25.96 & 22.03 & 44.29 & 34.25 \\
\hline Moldova & 17.99 & 13.26 & 36.9 & 31.5 & Poland & 23.38 & 16.61 & 41.3 & 33.6 \\
\hline Croatia & 24.91 & 21.43 & 47.1 & 37.9 & Spain & 24.64 & 20.46 & 42.3 & 33.5 \\
\hline \begin{tabular}{|l|} 
Bosnia- \\
Herzegovina
\end{tabular} & 21.02 & 17.56 & 42.4 & 37.0 & Ukraine & 23.09 & 19.33 & 42.1 & 33.1 \\
\hline Norway & 34.81 & 19.02 & 49.9 & 38.0 & Italy & 23.56 & 24.52 & 49.5 & 42.9 \\
\hline Georgia & 22.14 & 11.94 & 29.6 & 25.8 & \begin{tabular}{|l} 
United \\
Kingdom \\
\end{tabular} & 22.28 & 17.21 & 41.6 & 33.2 \\
\hline Finland & 30.28 & 25.29 & 55.6 & 44.1 & France & 29.93 & 28.32 & 56.6 & 45.3 \\
\hline Slovakia & 26.23 & 19.55 & 42.4 & 32.7 & Turkey & 19.87 & 13.77 & 34.1 & 25.5 \\
\hline Denmark & 34.88 & 20.57 & 53.4 & 45.9 & Germany & 26.88 & 25.95 & 43.9 & 37.6 \\
\hline Israel & 28.86 & 12.49 & 39.8 & 31.2 & Russia & 25.99 & 18.01 & 35.4 & 22.2 \\
\hline Average - c3 & 26.84 & 17.26 & 42.45 & 34.72 & Average - c6 & 24.40 & 20.47 & 42.98 & 34.09 \\
\hline
\end{tabular}

Sources: IEF, 2019; EFW, 2019; own calculations.

In addition, if the statistical analysis is performed, i.e., two-sample t-test assuming unequal variances, it is evident that we cannot deliver a proposition that larger European states (more than 10 million residents) have smaller budgetary government than smaller European states (less than 10 million residents). Threshold of 10 million residents to distinguish smaller and larger states is taken in order to increase the compared sample sizes for the statistical considerations. The observed difference between the sample means for three budgetary categories, i.e. governmental consumption spending, governmental total spending, and tax burden is not convincing enough to say that the average share of the stated categories between smaller and larger states differs significantly (see Table 2). 
In fact, the vice versa even holds for the governmental transfer expenditures, which tend to be on average even lower in smaller states, the fact that can be partially attributed that the data are from the period when the majority of European countries experienced economic boom, which tends to, according to prepositions, benefit relatively more to more open economies. Since economic openness is also related to the size of state with negative relationship, this tends to suggest that during the economic boom, smaller states are better off, and they consequently have fewer social problems on average, but this problem explodes during the economic downturn.

Table 2: Testing the sample means of budgetary categories for smaller and larger states

\begin{tabular}{|l|c|c|c|c|c|c|c|c|}
\hline & \multicolumn{2}{|c|}{$\begin{array}{c}\text { Consumption } \\
\text { spending }\end{array}$} & \multicolumn{2}{c|}{ Transfer spending } & \multicolumn{2}{c|}{ Total spending } & \multicolumn{2}{c|}{ Tax burden } \\
\hline & $\begin{array}{c}\text { Smaller } \\
\text { states, } \\
\mathrm{N}=28\end{array}$ & $\begin{array}{c}\text { Larger } \\
\text { states, } \\
\mathrm{N}=16\end{array}$ & $\begin{array}{c}\text { Smaller } \\
\text { states, } \\
\mathrm{N}=28\end{array}$ & $\begin{array}{c}\text { Larger } \\
\text { states, } \\
\mathrm{N}=16\end{array}$ & $\begin{array}{c}\text { Smaller } \\
\text { states, } \\
\mathrm{N}=28\end{array}$ & $\begin{array}{c}\text { Larger } \\
\text { states, } \\
\mathrm{N}=16\end{array}$ & $\begin{array}{c}\text { Smaller } \\
\text { states, } \\
\mathrm{N}=28\end{array}$ & $\begin{array}{c}\text { Larger } \\
\text { states, }=16\end{array}$ \\
\hline Mean & 24.81679 & 25.0825 & 16.60786 & 21.14813 & 40.66429 & 43.55 & 33.83571 & 34.16875 \\
\hline Variance & 42.89792 & 20.85579 & 24.66271 & 25.94204 & 62.08683 & 44.57333 & 43.5172 & 49.94629 \\
\hline $\mathrm{t}$ Stat & -0.1578 & & -2.87026 & & -1.29012 & & -0.15401 & \\
\hline $\begin{array}{l}\mathrm{P}(\mathrm{T}<=\mathrm{t}) \\
\text { one-tail }\end{array}$ & 0.437706 & & 0.003663 & & 0.102618 & & 0.439315 & \\
\hline $\begin{array}{l}\mathrm{t} \quad \mathrm{Critical} \\
\text { one-tail }\end{array}$ & 1.683851 & & 1.695519 & & 1.688298 & & 1.697261 & \\
\hline $\begin{array}{l}\mathrm{P}(\mathrm{T}<=\mathrm{t}) \\
\text { two-tail }\end{array}$ & 0.875411 & & 0.007326 & & 0.205236 & & 0.87863 & \\
\hline $\begin{array}{l}\mathrm{t} \quad \text { Critical } \\
\text { two-tail }\end{array}$ & 2.021075 & & 2.039513 & & 2.028094 & & 2.042272 & \\
\hline
\end{tabular}

Source: own calculations based on the data from Table 1.

Table 3 represents the so-called non-budgetary government and quality of governance indicators, represented by five indicators, ranging from the extent of regulation to the perception of governmental integrity. Here the higher number indicates the better outcome, i.e. less regulation, more investment freedom, larger judicial effectiveness, better functioning legal system and property rights, as well as larger governmental integrity. We further acknowledge that the indicators like investment freedom, judicial effectiveness, functioning of the legal system and government integrity level also directly correspond to the indicators of the quality of governance, whereas regulation relates more to indicating one of the dimensions of the size and scope of government, as pointed out earlier.

Table 3: Non-budgetary government and quality of governance indicators for selected European states

\begin{tabular}{|c|c|c|c|c|c|c|c|c|c|c|c|}
\hline $\begin{array}{l}\text { State/ } \\
\text { Indicator }\end{array}$ & $\begin{array}{l}\text { Regu- } \\
\text { lation }\end{array}$ & $\begin{array}{l}\text { Inv. } \\
\text { Free- } \\
\text { dom }\end{array}$ & $\begin{array}{l}\text { Judicial } \\
\text { Effect. }\end{array}$ & $\begin{array}{l}\text { Legal } \\
\text { system } \\
\text { and } \\
\text { property } \\
\text { rights }\end{array}$ & $\begin{array}{l}\text { Gov't } \\
\text { Integrity }\end{array}$ & $\begin{array}{l}\text { State/ } \\
\text { Indicator }\end{array}$ & $\begin{array}{l}\text { Regu- } \\
\text { lation }\end{array}$ & $\begin{array}{l}\text { Inv. } \\
\text { Free- } \\
\text { dom }\end{array}$ & $\begin{array}{l}\text { Judicial } \\
\text { Effect. }\end{array}$ & $\begin{array}{l}\text { Legal } \\
\text { system } \\
\text { and } \\
\text { property } \\
\text { rights }\end{array}$ & $\begin{array}{l}\text { Gov't } \\
\text { Integrity }\end{array}$ \\
\hline Iceland & 8.01 & 85 & 63.8 & 8.40 & 83.8 & Bulgaria & 7.61 & 70 & 41.9 & 4.83 & 35.1 \\
\hline Malta & 8.17 & 85 & 50.4 & 6.65 & 50.3 & Switzerland & 8.48 & 85 & 82.0 & 8.50 & 88.0 \\
\hline Luxembourg & 7.87 & 95 & 72.4 & 8.35 & 85.8 & Austria & 7.37 & 90 & 71.3 & 7.92 & 77.4 \\
\hline Montenegro & 6.94 & 75 & 51.8 & 4.92 & 39.5 & Sweden & 8.23 & 85 & 84.0 & 7.82 & 88.0 \\
\hline Cyprus & 7.55 & 75 & 48.1 & 5.94 & 43.7 & Serbia & 7.15 & 70 & 44.8 & 4.95 & 37.2 \\
\hline Estonia & 8.20 & 90 & 76.0 & 7.44 & 73.1 & Hungary & 7.63 & 80 & 45.2 & 5.92 & 35.3 \\
\hline Average - c1 & 7.79 & 84.17 & 60.42 & 6.95 & 62.70 & Average - c4 & 7.75 & 80.00 & 61.53 & 6.65 & 60.17 \\
\hline \begin{tabular}{|l|} 
Slovenia \\
\end{tabular} & 6.85 & 70 & 46.5 & 6.22 & 53.6 & Czechia & 8.09 & 80 & 47.6 & 6.30 & 52.1 \\
\hline N. Macedonia & 8.20 & 65 & 60.7 & 5.07 & 44.7 & Belarus & 6.38 & 30 & 51.7 & 5.53 & 37.7 \\
\hline Latvia & 7.66 & 85 & 48.4 & 6.20 & 35.5 & Belgium & 8.10 & 85 & 61.6 & 7.07 & 72.5 \\
\hline Armenia & 7.38 & 75 & 46.3 & 5.81 & 38.6 & Portugal & 7.18 & 70 & 64.3 & 6.98 & 59.5 \\
\hline Albania & 6.91 & 70 & 30.6 & 5.07 & 40.4 & Greece & 6.43 & 55 & 49.5 & 5.78 & 37.7 \\
\hline Lithuania & 8.04 & 80 & 61.2 & 6.50 & 47.8 & Netherlands & 8.27 & 90 & 74.7 & 8.16 & 89.1 \\
\hline Average - c2 & 7.50 & 74.17 & 48.95 & 5.81 & 43.43 & Romania & 7.78 & 70 & 51.9 & 6.04 & 39.8 \\
\hline
\end{tabular}




\begin{tabular}{|l|c|c|c|c|c|l|c|c|c|c|c|}
\hline Ireland & 8.47 & 90 & 68.4 & 7.72 & 78.0 & Average - c5 & 7.46 & 68.57 & 57.33 & 6.55 & 55.49 \\
\hline Moldova & 6.91 & 55 & 29.6 & 4.34 & 25.4 & Poland & 7.59 & 80 & 44.0 & 5.56 & 49.8 \\
\hline Croatia & 7.29 & 75 & 42.9 & 5.48 & 38.6 & Spain & 7.43 & 85 & 51.4 & 6.80 & 51.9 \\
\hline $\begin{array}{l}\text { Bosnia- } \\
\text { Herzegovina }\end{array}$ & 7.41 & 65 & 37.9 & 4.13 & 30.2 & Ukraine & 6.86 & 35 & 31.5 & 4.52 & 29.6 \\
\hline Norway & 7.73 & 75 & 81.2 & 8.68 & 92.3 & Italy & 7.49 & 85 & 49.8 & 5.71 & 43.7 \\
\hline Georgia & 8.49 & 80 & 54.6 & 6.31 & 58.5 & $\begin{array}{l}\text { United } \\
\text { Kingdom }\end{array}$ & 8.23 & 90 & 85.9 & 7.85 & 83.8 \\
\hline Finland & 7.72 & 85 & 81.2 & 8.80 & 92.5 & France & 7.46 & 75 & 66.1 & 6.92 & 67.9 \\
\hline Slovakia & 7.58 & 75 & 37.2 & 5.59 & 37.7 & Turkey & 6.63 & 70 & 49.8 & 4.78 & 41.2 \\
\hline Denmark & 8.32 & 90 & 77.8 & 8.08 & 85.8 & Germany & 7.99 & 80 & 75.4 & 7.44 & 81.3 \\
\hline Israel & 7.41 & 75 & 73.4 & 6.16 & 67.9 & Russia & 6.53 & 30 & 45.1 & 4.96 & 36.6 \\
\hline Average-c3 & 7.73 & 76.50 & 58.42 & 6.53 & 60.69 & Average - c6 & 7.36 & 70.00 & 55.44 & 6.06 & 53.98 \\
\hline
\end{tabular}

Sources: IEF, 2019; EFW, 2018; own calculations.

Following, statistical analysis below presents the outcome of group tests, where 10 million residents is taken as a threshold to distinguish smaller and larger European states. This is performed in order to increase the compared sample sizes for the statistical considerations. We can observe that there is actually major difference only in relation to the extent of regulation and investment freedom, where smaller states are less regulated and more investor friendly in comparison to larger states, but only if we liberally assume 10\% statistical significance margin (see Table 4). Interestingly, there is no statistically significant difference in relation to the other indicators for the quality of governance, thus, the state size is not one of the factors that would affect those outcomes, at least not in the European context. Still, it needs to be acknowledged that smaller states tend to have, on average, larger judicial effectiveness, better legal system, and government integrity is larger, as indicated by the results in the table below, but the differences between smaller and larger states are not statistically significant.

Table 4: Testing the sample means of non-budgetary categories for smaller and larger states

\begin{tabular}{|l|c|c|c|c|c|c|c|c|c|c|}
\hline & \multicolumn{2}{|c|}{ Regulation } & \multicolumn{2}{c|}{$\begin{array}{c}\text { Investment } \\
\text { Freedom }\end{array}$} & \multicolumn{2}{c|}{$\begin{array}{c}\text { Judicial } \\
\text { Effectiveness }\end{array}$} & \multicolumn{2}{c|}{ Legal System } & \multicolumn{2}{c|}{ Integrity } \\
\hline & $\begin{array}{c}\text { Smaller } \\
\text { states, } \\
\mathrm{N}=28\end{array}$ & $\begin{array}{c}\text { Larger } \\
\text { states, } \\
\mathrm{N}=16\end{array}$ & $\begin{array}{c}\text { Smaller } \\
\text { states, } \\
\mathrm{N}=28\end{array}$ & $\begin{array}{c}\text { Larger } \\
\text { states, } \\
\mathrm{N}=16\end{array}$ & $\begin{array}{c}\text { Smaller } \\
\text { states, } \\
\mathrm{N}=28\end{array}$ & $\begin{array}{c}\text { Larger } \\
\text { states, } \\
\mathrm{N}=16\end{array}$ & $\begin{array}{c}\text { Smaller } \\
\text { states, } \\
\mathrm{N}=28\end{array}$ & $\begin{array}{c}\text { Larger } \\
\text { states, } \\
\mathrm{N}=16\end{array}$ & $\begin{array}{c}\text { Smaller } \\
\text { states, } \\
\mathrm{N}=28\end{array}$ & $\begin{array}{c}\text { Larger } \\
\text { states, } \\
\mathrm{N}=16\end{array}$ \\
\hline Mean & 7.6993 & 7.4025 & 78.393 & 69.375 & 57.486 & 56.269 & 6.4928 & 6.275 & 57.311 & 54.637 \\
\hline Variance & 0.2557 & 0.4416 & 87.136 & 429.58 & 281.64 & 195.36 & 2.0407 & 1.196 & 506.02 & 356.75 \\
\hline $\mathrm{t}$ Stat & 1.5485 & & 1.647 & & 0.2579 & & 0.5670 & & 0.4207 & \\
\hline $\begin{array}{l}\mathrm{P}(\mathrm{T}<=\mathrm{t}) \\
\text { one-tail }\end{array}$ & 0.0670 & & 0.0579 & & 0.3990 & & 0.2870 & & 0.3382 & \\
\hline $\begin{array}{l}\mathrm{t} \text { Critical } \\
\text { one-tail }\end{array}$ & 1.7081 & & 1.7291 & & 1.6883 & & 1.6859 & & 1.6883 & \\
\hline $\begin{array}{l}\mathrm{P}(\mathrm{T}<=\mathrm{t}) \\
\text { two-tail }\end{array}$ & 0.1341 & & 0.1159 & & 0.7980 & & 0.5741 & & 0.6764 & \\
\hline $\begin{array}{l}\mathrm{t} \text { Critical } \\
\text { two-tail }\end{array}$ & 2.0595 & & 2.0930 & & 2.0281 & & 2.0244 & & 2.0281 & \\
\hline
\end{tabular}

Sources: own calculations based on the data from Table 3.

The results of the study suggest that the effect of the size of the state does not necessary favor larger states in respect to the smaller size of government due to the potential scale economies. Namely, the structure of spending, institutional context, and innovations in public service delivery modes do matter, among others. Namely, what the existing literature has recognized that the concept of administrative capacity itself is changing particularly so for small states. Here, regulation is often based on governance structures that are widely dispersed, and they are located outside the traditional boundaries of the administration. In these states, governance is transformed into a type of meta-governance that consists of the enrolment, legitimization and monitoring of the various governance and regulatory resources. In this context, since size of small states creates limits and international dependency grows; small states are seeking to oversize international presence by being innovative and open, and more importantly, by being economically unique, both in terms of domestic markets and societies, as well as in terms of exports. Thus, innovative approach of small states is that they replace the economies of scale with highly specialized economies of scope that can be scaled up to global markets (Kattel et al., 2011). 
Moreover, small states are overcoming the handicaps of their size, and the prime importance in that effort has been in finding ways how to reduce the costs and increase the effectiveness of public goods and services. This has been done through the use of international cooperation to reduce the per-unit costs of physical infrastructure, and through the use of outsourcing of government functions as a means of reducing the costs and improving the quality of some public goods and services (Favaro, 2008). Namely, small states have been experiencing, other things being equal, high per unit costs of production, especially in activities where fixed costs are significant, which led to the high share of government consumption in GDP, and this has been an indicator of the high cost of production of public goods and services (Rodrik, 1998). This problem was addressed by the outsourcing of public service provision, through cooperation with other countries, through the outsourcing of government functions to regional organizations, or through the outsourcing via international treaties (e.g., defence). Still, the most common form of outsourcing has been creating regional bodies to handle certain functions that would otherwise be carried out by individual states (see, e.g., Favaro, 2008).

In the context of the presented research, what are the implications that are to be delivered from the current COVID-19 related crisis? The current coronavirus (COVID-19) pandemic has caused one of the largest global health crises, and caused the situation of the Great Lockdown, term describing the current crisis, as coined by the IMF. In the context of small state studies, it is to be argued that they are the ones that should be hard hit. Namely, current lockdown has caused also the enormous reduction in the foreign direct investments in the range up to 40 percent (UNIDO, 2020), and in the reduction in global exports, where particularly EU is under attack (UNCTAD, 2020). Namely, small states tend to be relatively much more open and integrated in to the global trade, thus the economic consequences of lockdown and associated return of (economic) nationalism are particularly evident for them. The data provided by the World Economic Outlook (2020) project a very harsh fall of GDP for some smaller European states in particular (e.g., Iceland, Latvia, Estonia, Lithuania, Slovenia, Croatia, San Marino etc.), in particular if we compare those projections to other larger countries. This should be evident also in the rising social security and transfer spending, in order to provide the necessary safety net for the residents.

\section{Conclusion}

The results of the study suggest that the effect of the size of the state does not necessary favour larger states in respect to the smaller size of government. But, we might argue, according to the results obtained, that smaller states tend to be less regulated and investment freedom is larger there, on average, in comparison to larger states, and this is also supported by statistical significance. Thus, although potential scale economies matter regarding the public services' provision, the structure of spending, institutional context, and innovations in public service delivery modes also have the role in shaping size and scope of the government. Moreover, also the prevailing economic environment is important, as economic booms obviously benefit smaller states also from social aspects, if we assume that transfer spending of government is highly volatile for those states. Since the research is exploratory, the intention was to give additional evidence on the issue under consideration, and additional insight into the topic is highly warranted, in particular as the sampling was based on data for selected European states. Thus, extending of sampling or redirection of its focus might reveal a new insight into the topic, in particular if the randomization is involved.

\section{Acknowledgements}

This publication is published with the support of the Erasmus+ programme of the European Union. It is part of the Jean Monnet Networks project Navigating the Storm: The Challenges of Small States in Europe.

The present study has been presented at the 12th International Conference "Economies of the Balkan and Eastern European Countries", EBEEC 2020, that has been held online in Opatija, Croatia from May 29th to 31 th 2020 (http://ebeec.ihu.gr).

\section{References}

Alesina, A., 2003, “The Size of Countries: Does it matter?”, Journal of the European Economic Association, 1, 2-3, pp. $301-316$.

Alesina, A. and Wacziarg, R., 1998, “Openness, Country Size and the Government”, Journal of Public Economics, 69, pp. 305-322.

Alesina, A. et al., 2005, "Trade, Growth and the Size of Countries”, Aghion, P. and Durlauf, S., Handbook of Economic Growth, North Holland, Amsterdam, pp. 1499-1542.

Babbie, E., 2007, The Practice of Social Research, $11^{\text {th }}$ Edition, Thompson-Walsworth, Belmont.

Brito, J.A., 2015, Defining Country Size: A Descriptive Analysis of Small and Large States, MPRA Paper No. 66149. MPRA, Munich.

Bukowski, S.I. and Bukowska, J.E., 2017, "Financial and fiscal crises, prices and EUR/USD rate of exchange", International Journal of Business and Economic Sciences Applied Research, 10, 3, pp. 73-79.

Eichner, T. and Wagener, A., 2002, Increases in Risk and the Welfare State, CESifo Working Paper Series No. 685. CESifo, Munich.

EFW, 2018, Economic Freedom of the World: 2018 Annual Report, Fraser Institute, Vancouver.

Farrell, H., 2020, “A Most Lonely Union”, Foreign Policy, April 2020.

Favaro, E.M., 2008, Small States, Smart Solutions: Improving Connectivity and Increasing the Effectiveness of Public Services, World Bank, Washington.

Goldsmith, A.A., 1999, “Africa’s Overgrown State Revisited: Bureaucracy and Economic Growth”, World Politics, 51, 4, pp. 520546. 
IEF, 2019, Index of Economic Freedom 2019, The Heritage Foundation, Washington.

Jetter, M. and Parmeter, C.F., 2015, “Trade Openness and Bigger Governments: The Role of Country Size Revisited", European Journal of Political Economy, 37, pp. 49-63.

Kattel, R. et al., 2011, "Small States, Innovation and Administrative Capacity", Bekkers, V. et al., Innovation in the Public Sector: Linking Capacity and Leadership, Palgrave Macmillan, Cheltenham, pp. 61-81.

Kaufmann, D. et al., 2007, Governance Matter VI: Aggretate \& In Governance 1996-2006, World Bank Policy Research Paper 4780, World Bank, Washington.

Maass, M., 2009, "The elusive definition of the small state”, International Politics, 46, 1, pp. 65-83.

National Research Council, 2012, Using Science as Evidence in Public Policy, The National Academies Press, Washington.

Olsson, O. and Hansson, G., 2011, "Country Size and the Rule of Law: Resuscitating Montesquieu”, European Economic Review, 55, 5, pp. 613-629.

Pryor, F., 2001, Quantitative Notes on the Extent of Governmental Regulations in Various OECD Nations. SSRN Working Paper, http://ssrn.com (May 2020).

Rodrik, D., 1998, "Why do more open economies have bigger governments?", Journal of Political Economy, 106, 5, pp. 997-1032.

Rodrik, D., 2000, Institutions for High-Quality Growth: What They are and How to Acquire Them, NBER Working Paper No. 7540, NBER, Cambridge (MA).

Skilling, D., 2018, "Talk of the end of the small economy model much exaggerated", The Straits Times, https://www.straitstimes.com (May 2020).

Streeten, P., 1993, “The Special Problems of Small Countries”, World Development, 21, 2, pp. 197-202.

TheGlobalEconomy, 2020, "Indicators", https://www.theglobaleconomy.com (December 2020).

Thorhallsson, B., 2019, Small States and Shelter Theory, Routledge, Abingdon.

UNCTAD, 2020, "Coronavirus could cut global investment by 40\%, new estimates show", http://www.unctad.org (May 2020).

UNIDO, 2020, "COVID-19 and the global contraction in FDI", http://www.unido.org (May 2020).

World Economic Outlook, 2020, The Great Lockdown, IMF, Washington. 